\title{
Causality Relationship between Exchange Rate and Stock Returns in India - An Analytical Study
}

\author{
V. K. Somasundaram ${ }^{1 *}$ and T. Muthukumaran ${ }^{2}$ \\ 'Head, PG \& Research Dept. of Corporate Secretaryship, \\ Bharathidasan Govt. College for Women, Puducherry India; drvkspondy@rediffmail.com \\ ${ }^{2} \mathrm{Head}$, Department of Management Studies, Saradha Gangadharan College, \\ Puducherry, India; muthukumaran1871981@gmail.com
}

\begin{abstract}
The present study tries to estimate causality relationship that exists between exchange rate and stock returns. The impact of exchange rate on the returns from stock in India is examined, by using periodical data from the beginning of 1997 to the close of 2014. Macro variables are considered for the study: Real Exchange Effective Rate (REER) and BSE SENSEX. The study reveals that there exists some relationship between these two elements found through Granger Causality Technique [8]. However, from the short run results one cannot confirm that the exchange rate does not influence return on shares and vice versa. This study asserts that the exchange rate neither affects stock returns nor stock return affects the exchange rate. Thus, the present study empirically proves that the former does not induce the latter and in turn stock returns have no influence over exchange rate.
\end{abstract}

Keywords: Causality Relationship, FEDAI, Macroeconomic Variables, REER

\section{Introduction}

The globalization process opened new vistas for development as unpredictable environment in the Indian economic scenario persisted for comparatively long time. Our investors' share purchasing behaviour is totally unpredictable and our stock market has emerged as the most active stock market of the world during the last decade or so. It has also gained the attention of the investors worldwide by enlarging the sphere. Its outcome effected in increase in terms of number of stakeholders, quantum of operations and market expansion. The quiet and continuous progress found in our capital market is remarkable. Within nine years, from 3,740 points on March 31st 1999, the SENSEX of India's premier Stock Exchange touched 21,000 points in the beginning of 2008. In India, only about two per cent of the adult is engaged in stock markets. But the entire economy's buoyancy or the adversity depends on the events that take place in the stock markets. It shows clearly that there is a considerable association among stock markets and economic condition. For example, Sensitivity Index as a proportion of India's Gross Domestic Product has multiplied from four per cent in 1978-79 to 78 per cent (approximately) in 2011-12. Thus, the household financial and monitory activities occupy a vital role in determining the occurrence of share market. G C Nath and Y V Reddy [1] assert that the share market being a significant portion of the fiscal system should have a methodical linkage with the basics of the economy, since the stock price denotes all the future cash flows discounted by the appropriate discount rate, which depend on many economic factors like GDP growth, wholesale price index, Interest rate, exchange

*Author for correspondence 
rate fluctuations, global and domestic oil prices, etc. The underlying relationships between the Sensitivity and select large-scale Economic Variables were tested by Bhattacharya and Mukherjee [2]. Golaka C Nath and G P Samanta [3] have empirically shown that the causal link is lacking between exchange rate and stock prices. Golaka C Nath and G P Samanta [4] have again empirically asseverated that much strong causal relationship certainly did not exist between the returns of these two markets. However, the symmetry between macro economic variables and share market indicators was revealed by the study of G C Nath and Y.V. Reddy [1] and Soumya Guha Deb and Jaydeep Mukherjee [5] tried to examine whether there is a sharp but negligible flow from the share market advancement to national progress. The effect of foreign exchange reserves and Inflation on the stock price is only limited as found by Gagan Deep Sharma [6]. The current work is an attempt to investigate the interaction between Exchange rate and Stock returns in India.

\section{Statement of the Problem}

According to modern financial theory, systematic factors affect the elongated return on financial asset. It means that security market has to boast a relationship with financial and monitory economy of the nation. Therefore, the said association is commonly analyzed in two ways. (i) The macro economic variables influencing the share market operations especially equity returns.(ii) Similarly, the stock market influenced by the macro economic variables. Although, there is much research about short run and long run association between universal economic variables and share markets especially in developed countries, still there is a gap in literature in this area in case of developing and fast developing economies. The present study is necessitated to fill this gap. The present study is aimed at evaluating and analyzing the exchange rate and share returns in India.

\section{Research Objectives}

- To identify the nature of relationship between Exchange Rate and Stock Returns in India

- To examine the causal nexus between Exchange Rate and Stock Returns in India

\section{Methodology}

\subsection{Data Source}

Secondary data were tapped from BSE, RBI, and CMIE reports. The relevant literature was gleaned from books, journals and magazines. The pressure of exchange rate on the share returns in India is studied, by applying periodical data from 1997 to 2014 to represent the era of both economic reformation and instability.

\subsection{Variables Justification}

\subsubsection{Dependent Variable}

\section{Stock Returns}

Stock returns has been computed by applying the forthcoming equation:

$$
\mathrm{R}_{\mathrm{t}=} \operatorname{In}\left(\mathrm{I}_{\mathrm{t}} / \mathrm{I}_{\mathrm{t}-1}\right)
$$

BSE SENSEX is taken as a proxy for equity returns. This Sensitivity index is generally considered to be the yardstick widely accepted in Indian Capital Market by individual and institutional investors. The index systematically is designed to suit the needs of all concerned stakeholders. Introduced in 1986, the index comprises of shares of 30 representative corporates and the base year is 1978-79 and the base value is 100 .

\subsubsection{Independent Variable}

\section{Exchange Rate}

REER (Real Effective Exchange Rate), the export based FEDAI rate based on bilateral average of five countries has been considered for changes in exchange rates. The exchange rates are calculated by adopting weighted average method taking into account the rates of the domestic currency and respective foreign currencies after due adjustments made in this behalf.

\subsection{Analytical Procedure}

Statistical and econometric tools have been used to test and verify the results of the study for their accuracy. As adopted by Emrah Ozbay [7] the Descriptive statistics, Correlation analysis, and Granger causality test developed by Granger C.W.J. [8] and which are generally adopted for examining the short-run inter-dependence between variables, the same have been applied in the present study too. The study also employs ADF (Augmented Dickey Fuller) test, PP (Phillips-Perron) test and KPSS (Kwiatkowski, Phillips, Schmidt. and Shin) test to find the unit roots in time series, since these tests were earlier applied by Nadeem Sohail and Zakir Hussain [9] and several others.

\subsection{Hypothesis}

To find out whether the exchange rate forms the basis for the stock returns, the following hypotheses are framed:

HuSS: International Journal of Research in Humanities and Social Sciences 
Ho: Exchange Rate does not cause Stock Returns Ho: Stock Returns does not cause Exchange Rate

\section{Relationship between Exchange Rate and Stock Returns [7]}

The influences of exchange rate variations on the economy normally rely heavily on the level of global business transactions across the countries and their trade balance. Therefore, the determining force will be ascertained by the level of control of import and export sectors of the economy. The above mentioned premise documents the fact that fluctuations in the exchange rate tend to make substantial relevance on a company's aggregate profits by participation in overseas venture, which in turn effect in volatility in share prices. The nature and kind of operations in which the organisation engaged perhaps decides the strength and stock price movements. No doubt, rise in our currency value causes imports economical and exports uneconomical.

Another important area is foreign investment, where there is established contact between the share market and exchange rates. Through often fluctuating spot exchange rates, the return on foreign investment made by way of stock are converted from one currency rate to another. Whereas, return obtained from investment is converted from depreciating currency to stronger one, the return automatically gets reduced and vice versa.

\section{Analysis and Interpretation}

The short run causality between Exchange Rate and Stock Returns is analyzed as below:
Table 1 depicts the abstract statistics on the levels of the variables and first difference. This statistical information contain the mean and the standard deviation, minimum, maximum, skewness and Kurtosis value for the period 199798 to 2012-13. The mean, median, maximum, minimum and standard deviation can determine the statistical behavior of the variables. It is observed from the table that stock returns over the period of study is maximum at 9.916 with a minimum of 7.961 , averaging at 8.932 with a standard deviation of 0.692 which all clearly confirm that there is no much fluctuations in the stock returns over the period of study at level specification. The analysis of exchange rate shows a maximum of 4.664 and a minimum of 4.468 , while the average accounts at 4.586 with a standard deviation of 0.042 which all indicate a steady movement of exchange rate over the period of study. The table also shows that average monthly stock returns as 0.9 per cent and the exchange rate as 0.1 per cent. However, the standard deviations of the differences in these variables indicate that exchange rate is less than stock returns. For a normal distribution, the skewness must be zero and kurtosis at three. The results demonstrate that the frequency distributions of the variables are abnormal. Jarque-Bera statistics also make it known that the frequency distribution of the underlying series does not fit normal distribution [10].

Table 2 discloses the nexus between exchange rate and share returns for both level specification and first difference. At level specification, the correlation between exchange rate and share returns is 0.18 , that is sizable at 5 percent level. It points out that there exists a positive relationship between the variables. No doubt, it is unsafe to find the correlation from unconnected data. Hence, at the first difference, the correlation between exchange rate and share returns is 0.16 , which is found to be considerable at 5

Table 1. Descriptive Statistics [7]

\begin{tabular}{lccc}
\hline Variables & \multicolumn{2}{c}{ Levels } & First Difference \\
\cline { 2 - 4 } & Stock Returns & Exchange Rate & Stock Returns \\
\hline Mean & 8.932 & 4.586 & 0.009 \\
Maximum & 9.916 & 4.664 & 0.193 \\
Minimum & 7.961 & 4.468 & -0.279 \\
Std. Dev. & 0.692 & 0.042 & 0.066 \\
Skewness & 0.076 & -0.454 & -0.615 \\
Kurtosis & 1.356 & 3.182 & 4.465 \\
Jarque-Bera & 21.799 & 6.847 & 29.138 \\
Probability & 0.000 & 0.033 & 0.000 \\
Sum & 1715 & 880 & 1.632 \\
Observations & 192 & 192 & 191 \\
\hline Source: Computed from Secondary Data & &
\end{tabular}


per cent level. It specifies that exchange rate has negligible positive correlation with stock returns. Thus, the study shows that the association between exchange rate and stock returns is established in India $(r \neq 0)$. However, worth mentioning point is that association certainly does not imply or rule out causality.
It is essential to examine the time series for stationary [9] before applying Granger causality test [8] and therefore, the ADF, PP, and KPSS statistics [9] results are provided in Table-3.

From Table 3, both exchange rate and share returns are found to be non-stationary.

Table 2. Correlation Analysis

\begin{tabular}{lllll}
\hline \multicolumn{4}{l}{ Correlation Coefficient $(\mathbf{r})$ between Exchange rate and Stock returns } \\
\hline Series & & $\mathbf{r}$ & t-Statistics & P-Value \\
\hline \multirow{2}{*}{ Exchange rate } & Level Specification & 0.18 & 2.43 & $0.02^{*}$ \\
& First Difference & 0.16 & 2.21 & $0.03^{*}$ \\
\hline
\end{tabular}

${ }^{*}$ Implies significant at $5 \%$ level.

Table 3. Unit Root Test [9]

\begin{tabular}{|c|c|c|c|}
\hline \multirow[b]{3}{*}{ Variables } & \multicolumn{3}{|c|}{ Augmented Dickey-Fuller test Statistics [9] } \\
\hline & \multicolumn{3}{|c|}{ Null Hypothesis: Variable is Not Stationary } \\
\hline & \multicolumn{2}{|r|}{ Level } & \multirow{2}{*}{$\begin{array}{c}\text { First Difference } \\
\text { Constant }\end{array}$} \\
\hline & Constant & Constant and trend & \\
\hline Stock Returns & -0.6675 & -2.2663 & -10.0411 \\
\hline \multirow[t]{2}{*}{ Exchange rate } & -3.5266 & -3.5295 & -9.5830 \\
\hline & \multicolumn{3}{|c|}{ Test Critical Value (Mac Kinnon 1996) } \\
\hline $1 \%$ Level & -3.4672 & -4.0104 & -3.4672 \\
\hline $5 \%$ Level & -2.8776 & -3.4354 & -2.8776 \\
\hline \multirow[t]{3}{*}{$10 \%$ Level } & -2.5754 & -3.1417 & -2.5754 \\
\hline & \multicolumn{3}{|c|}{ Phillips - Perron test Statistics [9] } \\
\hline & \multicolumn{3}{|c|}{ Null Hypothesis: Variable is Not Stationary } \\
\hline \multirow[t]{2}{*}{ Variables } & \multicolumn{2}{|r|}{ Level } & First Difference \\
\hline & Constant & Constant and trend & Constant \\
\hline Stock Returns & -0.6227 & -2.1758 & -10.0274 \\
\hline \multirow[t]{2}{*}{ Exchange rate } & -3.5390 & -3.5405 & -14.5401 \\
\hline & \multicolumn{3}{|c|}{ Test Critical Value (Mac Kinnon 1996) } \\
\hline $1 \%$ Level & -3.4670 & -4.0101 & -3.4670 \\
\hline $5 \%$ Level & -2.8775 & -3.4351 & -2.8775 \\
\hline \multirow[t]{3}{*}{$10 \%$ Level } & -2.5754 & -3.1416 & -2.5754 \\
\hline & \multicolumn{3}{|c|}{ Kwaitkowshi-Phillips-Schmdist-skin test statistics[9] } \\
\hline & \multicolumn{3}{|c|}{ Null Hypothesis: Variable is Stationary } \\
\hline \multirow[t]{2}{*}{ Variables } & \multicolumn{2}{|c|}{ Level } & First Difference \\
\hline & Constant & Constant and trend & Constant \\
\hline Stock Returns & 1.5244 & 0.2070 & 0.0931 \\
\hline \multirow[t]{2}{*}{ Exchange rate } & 0.0549 & 0.0520 & 0.0382 \\
\hline & \multicolumn{3}{|c|}{ Test Critical Value (Mac Kinnon 1996) } \\
\hline $1 \%$ Level & 0.7390 & 0.2160 & 0.7390 \\
\hline $5 \%$ Level & 0.4630 & 0.1460 & 0.4630 \\
\hline $10 \%$ Level & 0.3420 & 0.1190 & 0.3420 \\
\hline
\end{tabular}


Table 4. Granger Causality Test [8]

\begin{tabular}{lcccc}
\hline Null Hypothesis & Lags & F-Statistics & Prob. & Results \\
\hline Exchange Rate does not cause Stock Returns & 2 & 0.65076 & 0.5229 & ACCEPT \\
Stock Returns does not cause Exchange Rate & 2 & 0.05006 & 0.9512 & ACCEPT \\
\hline
\end{tabular}

Table 4a. Exchange rate versus Equity returns

\begin{tabular}{lccc}
\hline Cause & Effect & Causality Inference & Relationship \\
\hline Exchange Rate & Stock Returns & Exchange Rate does not cause Stock Returns & No Relation \\
Stock Returns & Exchange Rate & Stock Returns does not cause Exchange Rate & No Relation \\
\hline
\end{tabular}

Due to the nature of international trade, fund flow from one to another country has increased manifold and thus exchange rate becomes a determinant of the profitability and also the share prices. The present study applied Granger Causality test to find out whether the changes in exchange rate effect adjustments in share returns, applying order one i.e. I (1).

The study's key finding that the exchange rate does not cause the stock returns and vice versa confirms the results of Soenen and Hennigar [11], Sangeeta Chakravarty [12], Basabi Bhattacharya and Jaydeep Mukherjee [2], Lakahmi R. Nair [13], Debabrata Mukhopadhyay and Nityananda Sarkar [14], Shahid Ahmed [10], and the result is contrary to Ray, Prantik and Vani Vina [15], Golaka C Nath and Y.V. Reddy [1], Bhattacharya and Mukherjee [2] for concluding empirically that there exists two way causation between stock price and rate of inflation alone, Nadeem Sohail and Zakir Hussain [9], Dharmendra Singh [16].

\section{Conclusion}

The current study attempted to assess the causality association between exchange rate and share returns. The findings reveal that short run causality is noticed between exchange rate and share returns. In fact, econometric models were applied to get more accuracy to the analysis and thereby the results bring to the fore that there is no such causality association between them. Therefore, the ultimate conclusion is that the exchange rate never influences share returns and vice versa. Thus, the study pragmatically proves that the exchange rate has no inducement on the stock returns and in turn stock returns has no influence over the exchange rate.

\section{References}

1. Golaka C.N., Reddy Y.V. "Macroeconomic Indicators and Stock prices-Indian Evidence”, The ICFAI journal of Applied Finance, p. 29-45, 2004.
2. Bhattacharya B., Mukherjee J. "Causal Relationship between Stock Market and Exchange Rate, Foreign Exchange Reserves and Value of Trade Balance: A Case Study for India”, 2002. Available: www.igidr.ac.in

3. Golaka C.N., Samanta G.P. "Relationship between Exchange Rate and Stock Prices in India - An Empirical Analysis", Social Science Research Network, e-Library, p. 1-11, Dec.7, 2003. Available: http://ssrn.com/abstract $=475823$

4. Golaka C.N., Samanta G.P. "Integration between Forex and Capital Markets in India: An Empirical Exploration”, Social Science Research Network, e-Library, p. 1-11, Dec.7, 2003. Available: http://ssrn.com/abstract $=475822$

5. Soumya G.D.., Mukherjee J. “Does Stock Market Development Cause Economic Growth - A Time Series Analysis for Indian Economy", International Research Journal of Finance and Economics, Iss. 21. Available: http://www.eurojournals. com/ finance.htm 2008

6. Gagan D.S., Mandeep M. "Impact of Macro-Economic Variables On Stock Prices in India", Global Journal of Management and Business Research, vol. 10(7), p. 19-26, 2010.

7. Ozbay E. "The Relationship between Stock Returns and Macroeconomic Factors: Evidence for Turkey”, Capital Markets Board of Turkey Publications, Academic Studies, p.1-60, 2009. Available: www.cmb.gov.tr

8. Granger C.W.J. "Investigating Causal Relations by Econometric Models and Cross-spectral Methods", Econometrica, vol. 37(3), p. 424-438, 1969. Available: http:// www.jstor.org/stable/1912791

9. Nadeem S., Hussain Z. "Long-run and Short-run Relationship between Macroeconomic variables and Stock Prices in Pakistan- The Case of Lahore Stock Exchange", Pakistan Economic and Social Review, Winter, vol. 47(2), p.183-198, 2009, Available: www.pu.edu.pk

10. Ahmed S. "Aggregate Economic Variables and Stock Markets in India", International Research Journal of Finance \& Economics, vol. 14, p. 141-164, 2008, Available: http://ssrn. com/abstract $=1693544$

11. Soenen L.A., Hennigar E.S. "An analysis of exchange rates and stock prices: The US experience between 1980 and 1986", Akron Business and Economic Review, vol. 19, p. 71-76, 1988. 
12. Chakravarty S. "Stock Market and Macro Economic Behavior in India", Institute of Economic Growth, Delhi: University Enclave, 2005. Available: sangeeta@iegindia.org

13. Lakshmi N.R. "Macroeconomic Determinants of Stock Market Development in India", NSB Management Review, vol. 1(1), p. 1-10, 2008. Available: www.pdfio.net/k-1800876. html\#download_area

14. MukhopadhyayD.,SarkarN. "Stockreturnandmacroeconomic fundamentals in model specification framework: evidence from Indian stock market", 2003. Available: www.isical. ac.in/ eru/2003-5

15. Ray P., Vina V. "Neural Network Models for Forecasting Mutual Fund Net Asset Value", $8^{\text {th }}$ Capital Markets Conference, Indian Institute of Capital Markets, Dec. 20, 2004. Available: http://ssrn.com/ abstract $=87226926$.

16. Singh D. "Causal Relationship between Macro-Economic Variables and Stock Market: A Case Study for India", Pakistan Journal of Social Science, vol. 30(2), p. 263-274, 2010.

\section{APPENDIX 1}

\section{List of Abbreviations:}

BSE- Bombay Stock Exchange

RBI- Reserve Bank of India

CMIE- Centre for Monitoring Indian Economy

FEDAI- Foreign Exchange Dealers' Association of India 